\title{
MAJALLAH AL-AHKÂM AL-ADLIYYAH \\ (ANALISIS HISTORIS DAN KEDUDUKANNYA DALAM SISTEM TATA HUKUM TURKI MODERN)
}

\author{
Chamim Tohari \\ Marmara University Istanbul Turkey \\ Email :chamimto@gmail.com
}

\begin{abstract}
This research disscuss about several matters which connecting with the book of Majalla al-Ahkâm al-Adliyya as following: (1) History, system, and methods of Majalla compiling; (2) This research disscuss about several matters which connecting with the book of Majalla al-Ahkâm al-Adliyya as following: (1) History, system, and methods of Majalla compiling; (2) Critics to the Majalla book; and (3) The position of the Majalla in the law system of the modern Turkey. This research using two methods, its library research and the field research. The results of this research were: (1) The main background of the Majalla codification movement is a difficult situation to make a same desicion about the law of something by the opinion of muslim judges of the Ottoman empire. The system of the Majalla compiling consist of the technical terms in Islamic law, principles of ijtihad in Islamic law, Islamic law about muamalah (economy and transaction), and the jurisdiction law. The methods which is used in codification of Majalla is takhrij and tarjih to the most important of the Hanafi's figh books. (2) Some critics made by the scholars of Islamic law to the Majalla, which is regard that the Majalla has been not achieving the standart as the sourch of privat law if it seen by the modern legislation theory. Another weakness of Majalla is it was only taken from Hanafi figh thought. (3) the position of Majalla book in the law system of the modern Turkey is as a spirit for implementation the newest of civil lae in Turkey, beside as the source of the informal law in the field of economy and transaction for the muslim sicuety in Turkey.
\end{abstract}

Keywords: Tanzîmat, Majallah al-Ahkâm al-Adliyyah, Turki Usmaniyah, Hanafiyah.

\footnotetext{
Abstrak

Penelitian ini mengkaji beberapa hal berkaitan dengan kitab Majallah alAhkâm al-Adliyyah, yakni: (1) sejarah, sistem, metode penyusunan kitab majallah; (2) kritik terhadap kitab Majallah; dan (3) kedudukan kitab Majallah dalam sistem tata hukum Turki modern. Penelitian ini menggunakan dua metode, library research atau penelitian pustaka dan field research, atau penelitian lapangan. Hasil penelitian ini adalah: (1) Kodifikasi kitab Majallah
} 
al-Ahkâm al-Adliyyah oleh pemerintahan Usmaniyah di Turki dilatarbelakangi adanya kesulitan yang dialami para hakim dalam menemukan rujukan hukum yang dapat mempersatukan pendapat mereka tentang masalah yang sama. Sistematika penyusunan kitab Majallah terdiri dari pengertian istilah-istilah dalam hukum Islam, kaidah-kaidah penetapan hukum Islam, materi hukum, serta hukum peradilan atau ushul al-hukm. Metode yang digunakan dalam penyusunan adalah metode takhrij dan tarjih terhadap kitab-kitab mu'tabarah mazhab Hanafi. (2) Beberapa kritikan muncul dari para ahli hukum Islam terhadap kitab Majallah, diantara kritikan tersebut adalah bahwa kitab Majallah tidak memenuhi standar sebagai Hukum Perdata jika dilihat berdasarkan teori perundang-undangan hukum modern. Kemelahan lainnya adalah sumber kitab Majallah yang hanya bersandar pada satu mazhab, yakni mazhab Hanafi. (3) Kedudukan kitab Majallah dalam sistem tata hukum Turki modern adalah sebagai spirit penerapan hukum perdata Turki, serta sebagai sumber hukum informal masyarakat muslim Turki dimana kitab Majallah berfungsi sebagai pedoman bermuamalah seharihari.

Kata Kunci : Tanzîmat, Majallah al-Ahkâm al-Adliyyah, Turki Usmaniyah, Hanafiyah.

\section{Pendahuluan}

Kerajaan Turki Usmaniyah yang oleh para sejarawan biasa disebut "The Ottoman Empire" merupakan dinasti Islam dengan usia terpanjang sepanjang sejarah peradaban Islam, yakni sekitar tujuh abad lebih (tepatnya sejak tahun 1299-1922 M). kerajaan ini jika dilihat dari sisi perkembangan ekonominya dapat dikelompokkan menjadi dua masa, yakni: Pertama, masa klasik (Nizhâm al-Qadîm) dan masa modern (Nizhâm al-jadîd). ${ }^{1}$

Pada masa klasik perekonomian Turki Usmaniyah lebih banyak digerakkan dan dikendalikan oleh bangsa Seljuk yang memiliki pengaruh kuat dalam pemerintahan. Masa ini terhitung sejak awal berdirinya dinasti Usmaniyah yakni pada tahun 1299 hingga akhir abad ke-18 M. pada masa ini pula pemerintah Usmaniyah sudah menerapkan sistem perpajakan (vergi sistemi) untuk masyarakat muslim, jizyah (cizye) untuk warga negara yang non muslim, di seluruh daerah kekuasaan Usmaniyah. Mereka, juga sudah mengenal sistem

1 Ahmed Tabakoglu, Islam Iktisadina Giris, (Istanbul: Dergah Yayinlari, 2008), h. 160 . 
wakaf (vakif sistemi) yang hasil pengelolaannya hingga kini masih dapat didapati dalam bentuk fasilitas-fasilitas sosial seperti sarana keagamaan, pendidikan dan kesehatan. ${ }^{2}$ Begitu pula hukum bisnis perdagangan, sistem keuangan dan ketenagakerjaan sangat diawasi pelaksanaannya oleh negara. Pada masa ini hukum Islam telah diterapkan oleh masyarakat Turki Usmaniyah, meskipun tidak menjadi hukum resmi pemerintah. Secara resmi Ottoman Empire dalam masalah hukum masih menggunakan hukum Romawi yang disebut Corpus Iuris Civilis. Mereka juga mengakui dan mempraktikkan hukum adat dalam menjalankan kegiatan ekonomi. ${ }^{3}$

Sedangkan masa modern perekonomian Turki Usmaniyah dimulai sekitar tahun $1790 \mathrm{M}$ hingga keruntuhan dinasti ini pada 1923 M. Secara umum dapat dikatakan bahwa sistem perekonomian Turki Usmaniyah dari sisi substansinya didasarkan pada aturan-aturan syariat Islam. Hak ini karena masyarakat Turki dikenal sebagai masyarakat muslim yang taat pada ajaran agamanya, disamping hukum Romawi dan hukum adat juga digunakan dalam mengatur sistem pemerintahannya. Pada masa sistem ekonomi modern inilah lahir sebuah kitab fiqh yang menjadi bagian dari konstitusi negara sekaligus menjadi dasar para hakim dalam memutuskan sengketa perkara muamalah di seluruh wilayah kekuasaan Turki Usmaniyah. Kitab tersebut dinamai "Majallah al-Ahkâm al-Adliyyah." Kitab yang disusun antara tahun 1868-1889 M tersebut dilatarbelakangi adanya kebutuhan para hakim (qâdhi) di kerajaan Turki Usmaniyah untuk berpegang pada satu pendapat dalam mazhab Hanafi dalam memutuskan masalah muamalah. Karena sebelum lahirnya kitab Majallah tersebut, para qadhi seringkali berbeda pendapat tentang satu masalah hukum yang sama, dikarenakan mereka menggunakan sumber rujukan yang berbeda, meskipun tetap dalam konteks mazhab Hanafi.

Tulisan ini dimaksudkan untuk mengkaji beberapa poin penting untuk dibahas tentang kitab Majallah al-Ahkâm al-Adliyyah ini yang meliputi: (1) sejarah, sistem, metode penyusunan kitab majallah; (2) kritik terhadap kitab Majallah; dan (3) kedudukan kitab Majallah dalam sistem tata hukum Turki modern. Tulisan ini menggunakan dua metode sekaligus, yakni (1) Library Research atau penelitian pustaka dengan menggunakan content analysis sebagai metode analisisnya; dan

2 Ibid, h. 168.

${ }^{3}$ M. Akif Aydin, Turk Hukuk Tarihi, (Istanbul: Beta Yayinlari, 2013), h. 169-

171. 
(2) Field Research, atau penelitian lapangan untuk mencari jawaban sejauh mana kedudukan dan fungsi kitab Majallah dalam sistem tata hukum Turki modern.

\section{Kondisi Sosial-Politik Turki Era Penyusunan Kitab Majallah}

Pada awal tahun $1800 \mathrm{M}$ kemunduran Khilafah Usmaniyah mulai tampak dengan semakin lemahnya control terhadap wilayahwilayah dibawah kekuasaannya, setelah sebelumnya kerajaan besar ini kehilangan wilayah kekuasaannya di daerah black sea dan Cremia akibat perang berkepanjangan melawan Rusia antara tahun 1768-1792. ${ }^{4}$ Kemunduran ini semakin tampak dengan lepasnya satu per-satu negeri yang sebelumnya dikuasai oleh kekhilafahan Usmaniyah. Misalnya Yunani yang melepaskan diri dari kerajaan Usmaniyah pada tahun 1829 M. Pada masa berikutnya disusul oleh Bosnia dan Bulgaria yang jatuh ke tangan Rusia pada tahun 1877, juga pada tahun yang sama Serbia dan Rumania berhasil melepaskan diri dan menjadi negara merdeka. Sementara wilayah lainnya di Afrika Utara yang menjadi kekuasaan Turki seperti Aljazair juga berhasil direbut oleh Perancis pada tahun 1830. Selain itu Mesir pada akhir abad ke-19 berhasil melepaskan diri dari Usmaniyah dan menjadi negara tersendiri di antara wilayah kekuasaan Usmaniyah lainnya. ${ }^{5}$

Kekalahan demi kekalahan yang diderita Turki Usmaniyah diantara penyebabnya adalah ketertinggalan negara ini dibidang teknologi, terutama teknologi kemiliteran. Selain tertinggal dibidang teknologi, Turki Usmaniyah juga tertinggal dalam bidang-bidang lainnya, termasuk ketertinggalan pada sistem tata hukum dan konstitusi yang digunakan. Sebelum masa Tanzîmat, pemerintahan Usmaniyah menggunakan hukum Islam sebagai undang-undang negara dalam bidang muamalah, sementara hukum Islam yang ada adalah produk masa lalu yang pada masa itu sedang mengalami kejumudan. Kondisi yang demikian tersebut menjadikan hukum Islam tidak selalu dapat menyelesaikan persoalan-persoalan baru yang dihadapi masyarakat. Apabila dilihat dari sisi historisnya, kemunduran atau kejumudan hukum Islam tidak saja terjadi di Turki, tetapi di seluruh wilayah negeri Islam. Sebagian pakar sejarah Islam

4 Erik J. Zurcher, Turkey A Modern History, (London-New York: I.B. Touris \& Co. Ltd, 1994), h. 21-79.

5 Philip K. Hitti, History of the Arab, cet. Ke-10, (New York: Mac Millan, 1976), h. 717-722. 
mengatakan bahwa masa stagnasi hukum Islam tersebut dimulai sejak invasi bangsa Monggol ke negeri-negeri Islam pada tahun $654 \mathrm{H}$ hingga munculnya kitab Majallah tahun 1286 H. $^{6}$

Suasana kejumudan atau stagnasi hukum Islam dinegeri-negeri Islam tersebut menyebabkan hukum Islam seolah tidak peka terhadap perubahan zaman, sehingga kitab-kitab fiqh yang ada seakan-akan tidak lagi relevan untuk menyelesaikan problematika yang dihadapi umat Islam pada masa itu. Keadaan tersebut membuat pemerintah Usmaniyah sadar bahwa ketertinggalan-ketertinggalan tersebut apabila didiamkan akan mengatarkan negara ke jurang kehancuran. Karena itu pemerintah Usmaniyah merasa perlu untuk segera bangkit dan melakukan perubahan-perubahan. Diantara tindakan konkrit yang dilakukan pemerintah Usmaniyah adalah dengan didirikannya universitas-universitas yang mengembangkan teknologi untuk menandingi kemajuan negara-negara Eropa. Dan untk mengatasi ketertingggalan dibidang sistem hukum pemerintah Usmaniyah melakukan reformasi hukum yang dalam sejarah disebut Tanzîmat. Salah satu yang menjadi bagian dari proyek Tanzîmat adalah kodifikasi hukum Islam yang disebut dengan kitab "Majallah al-Ahkam al-Adliyah."

Kitab Majallah disusun dalam situasi dimana pemerintah Usmaniyah sedang gencar melakukan reformasi dibidang hukum. Reformasi hukum (Tanzîmat) diawali dengan instruksi Sultan Abdul Majid I (1839-1861 M) yang diumumkan di Gulhane Park pada tanggal 3 Nopember 1839 M,7 sesaat setelah beliau diangkat menjadi Khalifah Usmaniyah. Sejak itulah Turki memulai reformasi hukumnya dengan mengganti sistem hukum sebelumnya yang diambil dari sistem hukum Konstantinopel dan adat dengan sistem hukum modern Barat. Masa Tanzîmat ini berakhir hingga tahun 1876 M, meskipun penulisan kitab Majallah itu sendiri berakhir pada tahun $1889 \mathrm{M} .^{8}$

${ }^{6}$ Fahretin Atar, Fikih Usulu, cet. Ke-10, (Istanbul: 2013), h. 441-442.

7 Sebagian pakar sejarah Ottoman seperti Niyazi Berkes mengaitkan Tanzîmat di Turki Usmaniyah dengan proyek sekularisasi di Turki yang dimotori oleh Mustafa Rashid Pasha, seorang birokrat Ottoman yang memperoleh pendidikan dari Barat dimana pemikirannya telah terkontaminasi oleh odeologi Barat setelah pada tahun 1835-1839 berkunjung ke negara-negara Eropa dan mempelajari kebudayaan dan ideologi Barat. Ia dikenal sebagai "The Father of Tanzîmat" atau pelopor gerakan Tanzîmat di Turki. Lihat Niyazi Berkes, The Development of Secularizn in Turkey, (Mc Gill: Mc Gill University Press, 1964), h. 144.

${ }^{8}$ Hayreddin Karaman, Islam Hukuk Tarihi, (Istanbul: Iz Yayincilik, 2012), h. 309. 
Mengenai hal-hal yang menjadi latar belakang dilakukannya gerakan reformasi hukum di Turki, dapat disebutkan sebagai berikut; (1) Terjadinya perkembangan dan perubahan sistem perekonomian dan perdagangan; (2) Kebutuhan akan hukum dan sistem perundangundangan yang relevan dengan kondisi pada masa itu; (3) Ekspansi negara-negara Barat ke dunia Islam yang terus-menerus sehingga menimbulkan perubahan dalam pranata sosial, politik dan ekonomi; dan (4) Meningkatnya interaksi warga muslim dengan non muslim dalam bidang muamalah (transaksi ekonomi). ${ }^{9}$

Poin-poin di atas menjadi sebab yang mendorong diadakannya reformasi hukum (Tanzîmat) di Turki, dimana penyusunan kitab Majallah merupakan bagian dari gerakan reformasi tersebut. Karena penyusunan kitab Majallah manjadi bagian dari Tanzîmat, maka dapat dikatakan bahwa hal-hal yang menjadi sebab Tanzîmat adalah hal-hal yang menjadi sebab disusunnya kitab Majallah pula. Karena secara garis besar penyusunan kitab Majallah adalah respons dari perubahan dan kebutuhan masyarakat Turki terhadap pembaharuan hukum Islam yang konkrit dan relevan.

\section{Sejarah Penulisan Kitab Majallah}

Para hakim dinasti Usmaniyah dibawah pemerintahan Sultan Abdul Hamid II (1842-1918 M), sebelum disusunnya kitab Majallah, didalam memutuskan permasalahan hukum khususnya hukum muamalah, selain menggunakan hukum Barat dan hukum adat juga banyak menggunakan fiqh mazhab Hanafi. Namun karena dalam mazhab Hanafi sendiri terdapat banyak perbedaan pendapat dalam satu masalah yang sama, kondisi seperti demikian ini menyulitkan para hakim dalam mengambil keputusan hukum. Atas dasar inilah kemudian disusun satu kitab fiqh yang bernama "Majallah al-Ahkâm alAdliyyah" yang dijadikan sebagai konstitusi negara dimana keputusan hukum dalam bidang muamalah harus didasarkan pada kitab tersebut. Kitab tersebut dimaksudkan untuk menghilangkan perbedaan pendapat dalam memutuskan perkara hukum oleh para hakim kerajaan. ${ }^{10}$

9 Fahretin Atar, Tanzîmat Fermani, (Diktat Mata Kuliah Islam Yargilama Hukuku, 2012). Makalah tidak dipublikasikan.

10 Mustafa Ahmad Zerka, Al-Madkhal al-Figh al-'Amm, Jilid I, (Jeddah: Dâr alBashîr, 2004), h. 236-238. 
Latar belakang penyusunan kitab Majallah tidak sekedar dimaksudkan untuk menghilangkan perbedaan putusan yang dibuat oleh para hakim Usmaniyyah, tetapi lebih pada unsur politis dimana Sultan Abdul Hamid II adalah seorang sultan yang memiliki keinginan kuat untuk mengembalikan kekhalifahan Turki Usmani menjadi negara yang sepenuhnya menerapkan syariat Islam, setelah sebelum pemerintahannya kerajaan Usmaniyah perlahan bergerak ke arah sekulerisme. ${ }^{11}$ Karena itu penyusunan dan pemberlakuan kitab Majallah menjadi bagian dari sumber hukum kerajaan adalah dalam rangka menghapus hukum-hukum lainnya terutama hukum perdata Barat yang saat itu juga berlaku dalam pemerintahan karena kebijakan penguasa sebelumnya. Selain itu, karena luasnya wilayah Ottoman yang kemudian berpengaruh pada perkembangan hubungan perdagangan dengan wilayah lain menyebabkan munculnya permasalahan hukum baru yang semakin kompleks, yang juga membutuhkan putusan hukum yang relevan dengan kondisi yang ada. Sementara hukum yang ada tidak selalu mampu memberikan jawaban hukum sebagaimana kondisi yag dihadapi. Sehingga pemerintah dan para ulama Usmaniyah merasa perlu menyusun kitab rujukan yang sekiranya paling relevan dengan kebutuhan masyarakat. Jadi dalam konteks ini, adanya upaya men-tarjih fiqh Hanafiyah untuk ditetapkan sebagau hukum negara dalam bentuk kitab Majallah tidak sekedar memilih pendapat yang terkuat dalam mazhab tersebut, melainkan juga memilih pendapat yang paling sesuai dengan permasalahan yang dihadapi masyarakat pada masa itu.

Penyusunan kitab Majallah dilakukan secara berjamaah oleh para ulama terkemuka mazhab Hanafi pada masa itu dibawah pimpinan Ahmed Cevdet Pasha (w. 1312 H/1895 M) sejak tahun 1868

11 Menurut pakar sejarah Ottoman, Mehmet Anik dan Niyazi Berkez, gerakan sekulerisme Dinasti Usmaniyah berawal pada masa pemerintahan Sultan Mahmud II (1808-1839 M) sejak didirikannya institusi pendidikan yang menyebarkan paham sekuler seperti Medical School tahun 1827 M, dan juga Military College tahun 1934 M. Menurut Berkez, Sultan Mahmud adalah seorang sultan yang mencoba memisahkan urusan keagamaan dengan urusan pemerintahan dan bahkan urusan sosial keduniaan. Bahkan pada masa pemerintahan Sultan Mahmud II tercatat pernah terjadi konflik antara kelompok pemerintah dengan kaum ulama terutama dalam masalah pendidikan dan peranan sosial. Karena itulah masa reformasi (Tanzîmat) dalam tubuh pemerintahan Usmaniyah terjadi pada masa ini, yakni sekitar tahun 1839M dan berakhir pada tahun 1876 M. Lihat Mehmet Anik, Two Axes Revolving Around the Discussions of Secularizm in Turkey, (Istanbul: Ilem, 2012), h. 1415. 
hingga tahun 1889 M. Pada masa tersebut pemerintahan dibawah kekuasaan Sultan Abdul Hamid II. Adapun para ulama yang terlibat dan menjadi anggota komisi penyusunan kitab Majallah diantaranya; Ahmed Cevdet Pasha (w. 1312 H/1895 M), Ahmed Hilmi Effendi (w. 1305 H/1888 M), Syeifuddin Ismail Effendi (w. 1299 H/1882 M), Flilbeli Halil Effendi (w. 1302 H/1885 M), Sirvanizade Ahmed Hulusi Effendi (w. 1306 H/1889 M), Kara Halil Effendi (w. 1299 H/1882 M), Ibn Abidinzade Alaudin Effendi (w. 1306 H/1889 M), Omer Hilmi Effendi (w. 1307 H/1889 M), Bagdadli Muhammed Emin Effendi (w. 1309 H/1891 M), Omer Hulusi Effendi (w. 1292 H/1875 M), Yunus Vehbi Effendi (w. 1322 H/1904 M), Kirimli Abdussettar Effendi (w. 1304 H/1887 M), Abdullatif Sukru Effendi (w. 1304 H/1887 M), dan Isa Ruhi Effendi (w. 1297 H/1880 M). Nama-nama ulama tersebut tertulis sebagai jamaah penyusun kitab Majallah ketika komisi ini masih bernama "Divan al-Ahkâm al-Adliyyah Dairesi". ${ }^{12}$

Semua nama-nama ulama tersebut wafat sebelum kitab Majallah selesai disusun. Hanya Ahmed Cevdet Pasha dan Omer Hilmi Effendi yang dapat menuntaskan penulisan kitab Majallah. Selanjutnya masuklah beberapa nama baru yang menggantikan anggota sebelumnya yang telah wafat, diantaranya Muhammad Nuri Effendi, Ali Haidar EffendiAl-Hacc Muhammad Effendi, serta Abdullah Sakir Effendi. Pada masa pergantian tersebut majelis ini diubah namanya menjadi "Bâb al-Fatwâ". ${ }^{13}$

Para ulama yang tergabung dalam jamaah penyusun kitab Majallah (Mecelle Cemiyeti) ini mengumpulkan pendapat-pendapat dalam mazhab Hanafi tentang tema-tema tertentu dalam idang hukum muamalah, kemudian diamillah pendapat yang menurut mereka paling kuat untuk ditetapkan dan ditulis ke dalam kitab Majallah. Penyusunan kitab ini memakan waktu kurang lebih sekitar 20an tahun. ${ }^{14}$ Kitab tersebut pertama kali disusun dalam bahasa Arab dan bahasa Turki. Penyususnan kitab Majallah dapat dikatakan sebagai kodifikasi fiqh Islam pertama dalam sistem konstitusi negara dimasa kemunduran Islam menuju masa kebangkitannya.

Lahirnya kitab Majallah kemudian menginspirasi negeri-negeri berpenduduk muslim lainnya untuk melakukan kodifikasi hukum

12 Abu al-Ula Mardin, Medeni Hukuk Cephesinden Ahmed Cevdet Pasha, Istanbul: (Istanbul Yayinlari, 1946), h. 160-166.

13 Ibid, h. 150-151.

14 Hayreddin Karaman, Islam Hukuk Tarihi, h. 311. 
Islam sebagai bentuk transformasi hukum Islam ke dalam sistem hukum negara. Transformasi hukum Islam ke dalam tata hukum negara terjadi di Mesir pada tahun 1980 M, Iraq pada tahun 1959 M, Libanon tahun 1942 M, Tunisia tahun 1958 M, Syria tahun 1953, Pakistan tahun 1949,15 dan Indonesia tahun 1974 hingga sekarang. ${ }^{16}$

Kitab Majallah, pada awal disahkannya menjadi dasar hukum negara berlaku di seluruh wilayah kekuasaan Usmaniyah. Bahkan setelah keruntuhan Khilafah Usmaniyah pun kitab tersebut masih digunakan sebagai undang-undang negara wilayah kekuasaan Usmaniyah seperti di Iraq hingga tahun 1951, Libanon hingga tahun 1934, dan Syria hingga tahun 1949. Kitab Majallah kemudian tidak lagi dipergunakan oleh negara-negara tersebut, bahkan di Turki sendiri kitab tersebut tidak lagi mendapatkan tempat dalam konstitusi negara sejak berlakunya Medeni Kanunu pada tahun 1926 M, yakni semacam hukum perdata Barat yang diterapkan sebagai pengganti kitab Majallah. Hanya saja, esensi kitab Majallah masih terjaga dengan adanya ketentuan perundangan yang menyatakan bahwa segala peraturan dalam Medeni Kanunu yang bertentangan dengan kitab Majallah dinyatakan tidak berlaku. ${ }^{17}$

\section{Sistematika dan Metode Penyusunan Kitab Majallah}

Sebenarnya ide awal disusunnya kitab Majallah adalah sebagai upaya pemerintahan Usmaniyah dalam mengoptimalkan peran hukum Islam dalam menghadapi permasalahan modern di bidang muamalah, yang memiliki kekhasan pemikiran mazhab resmi negara, yakni mazhab Hanafiyah. Sebelum munculnya kitab Majallah, para hakim dituntut untuk memberikan putusannya tanpa adanya pedoman fiqh yang baku, sehingga kerap kali putusan para hakim berbeda antara satu dengan lainnya meskipun dalam masalah yang sama. Demikianlah hal tersebut terus berlanjut hingga kemunculan kitab Majallah.

Kitab Majallah terdiri dari 16 kitab, 52 bab, dan 1851 pasal. Pada seratus halaman pertama berisi muqaddimah yang juga terdiri dari 99 kaidah fiqh. Kaidah-kaidah tersebut menempati posisi penting dalam kitab Majallah, karena kaidah-kaidah tersebut adalah prinsip yang sekaligus sebagai penghubung antara konsep fiqh dengan metode

15 Ibid, h. 304.

${ }^{16}$ Lihat Chamim Tohari, Fiqh Keindonesiaan: Transformasi Hukum Islam Dalam Sistem Tata Hukum Di Indonesia, (Jurnal Analisis, Vol. 15, No. 2, Desember 2015), h. 15.

17 Hayreddin Karaman, Islam Hukuk Tarihi, h. 318. 
penerapannya dalam menyelesaikan realitas permasalahan yang dihadapi. Kaidah-kaidah tersebut juga menjadi dasar dimana tiap bab dan pasal dalam kitab Majallah tersebut ditetapkan. Karenanya dalam menggunakan tiap pasal aturan dalam kitab Majallah, para hakim tidak dapat terlepas dari kaidah-kaidah yang ditulis dalam kitab tersebut. ${ }^{18}$

Sebagai sebuah undang-undang hukum perdata, kitab Majallah sebenarnya tidak mencakup semua masalah perdata. Apabila dilihat dari cakupan ilmu fiqh, kitab Majallah tidak memuat beberapa bidang pokok yang menjadi bagian penting kajian ilmu fiqh seperti fiqh ibadah, hukum keluarga (al-ahwal al-syahsiyah), dan hukum 'uqubah (al-ahkam al-'uqubat). Menurut Mustafa Ahmad Zarqa, hal tersebut karena kitab Majallah tidak dipersiapkan untuk memutuskan perkaraperkara dalam ranah hukum privat, tetapi untuk menyelesaikan perkara-perkara perdata yang berkaitan dengan muamalah dan perekonomian. Sehingga untuk masalah seperti hukum pernikahan dan kewarisan, pemerintah Usmaniyah secara tersendiri melakukan kodifikasi tersendiri menjelang kekhilafahan Usmaniyah berakhir, tepatnya pada tahun 1917 M, yang mana hasil kodifikasi tersebut disebut sebagai "Hukuki Aile Kararnamesi" atau "Putusan-putusan Hukum Keluarga."19 Selain itu, tidak adanya al-ahkam al-uqubah dalam kitab Majallah karena perihal hukuman baik pidana maupun perdata telah diatur tersendiri dalam Undang-undang yang disebut dengan Ceza Kanunu pada tahun 1840 M.

Untuk lebih jelasnya, berikut sistematika penulisan kitab Majallah al-Ahkâm al-Adliyah;

Muqadimah (halaman 1-100)

1. Kitab al-Buyû' (Muqadimah +7 bab, halaman 101-403)

2. Kitab al-Ijârah (Muqadimah +8 bab, halaman 403-611)

3. Kitab al-Kafâlah (Muqadimah +3 bab, halaman 612-672)

4. Kitab al-Hawâlah (Muqadimah +2 bab, halaman 673-700)

5. Kitab al-Rahn (Muqadimah +4 bab, halaman 701-761)

6. Kitab al-Amânah (Muqadimah +3 bab, halaman 762-832)

7. Kitab al-Hibah (Muqadimah +2 bab, halaman 833-880)

8. Kitab al-Gasb wa al-Itlâf (Muqadimah +2 bab, halaman 881-940)

18 Fahretin Atar, Islam Yargilama Hukukun Esaslari, (Istanbul: MU Ilahiyat Yayinlari, 2012), h. 6-7.

${ }^{19}$ Mustafa Ahmad Zerka, Al-Madkhal al-Fiqh al-'Amm, Jilid I, h. 240. 
9. Kitab al-Hajr wa al-Ikrâh wa al-Suf'ah (Muqadimah +3 bab, halaman 941-1044)

10. Kitab al-Syirkah (Muqadimah +8 bab, halaman 1045-1148)

11. Kitab al-Wakâlah (Muqadimah + 3 bab, halaman 1149-1530)

12. Kitab al-Sulh wa al-Ibra (Muqadimah +4 bab, halaman 15311571)

13. Kitab al-Ikrâr (Muqadimah +4 bab, halaman 1572-1612)

14. Kitab al-Da'fa (Muqadimah + 12 bab, halaman 1613-1675)

15. Kitab al-Bayyinah wa al-Tahlif (Muqadimah $+4 \mathrm{bab}$, halaman 1676-1783)

16. Kitab al-Qadhâ' (Muqadimah + 4 bab, halaman 1784-1851)

Kitab Majallah juga membahas dan menetapkan aturan-aturan tentang peradilan pada bagian akhir isi kitab. Seperti masalah perdamaian (sulh), pembebasan (ibra), sumpah (ikrâr), pembuktian (albayyinât), dan peradilan (qadhấ) diatur secara tertib dalam kitab Majallah. Karena itu dapat dikatakan bahwa kitab Majallah tidak sekedar kitab hukum perdata yang mengatur ketentuan bertransaksi berdasarkan hukum Islam, tetapi sekaligus sebagai kitab hukum acara perdata di bidang muamalah yang berlaku diseluruh wilayah kekuasaan Usmaniyah. ${ }^{20}$

Pada masa sekarang penyusunan undang-undang umumnya menggunakan metode kasuistik atau undang-undang disusun berdasarkan kebutuhan untuk suatu permasalahan tertentu. Apabila dilihat dari sisi tersebut maka sebenarnya mekanisme penyusunan kitab Majallah sudah cukup modern, setidaknya pada masa reformasi hukum (Tanzîmat) di Turki pada masa itu. Penyusunan bab per bab kitab majallah dilakukan secara induktif dengan menggunakan kaidah-kaidah khusus di bidang muamalah atau transaksi, untuk kemudian hasilnya diuji dengan menggunakan kaidah-kaidah asasiyah atau kaidah fiqh yang pokok. ${ }^{21}$

\section{Metode Penyusunan Kitab Majallah}

Para ulama dalam upayanya menemukan solusi atas suatu permasalahan hukum Islam pada masa awal pembentukan kitab Majallah, para ulama Turki setidaknya menggunakan beberapa metode berikut: (1) Menggunakan al-Qur'an dan Sunnah serta metodemetode dalam ilmu ushul fiqh sebagai sumber dan metode

20 Fahretin Atar, Islam Yargilama Hukukun Esaslari, h. 7.

${ }^{21}$ Ozman Ozturk, Osmanli Hukuk Tarihinde Mecelle, (Istanbul: Iz Yayincilik, 1973), h. 40-82. 
mengeluarkan hukum (takhrij al-hukm);22 (2) Melakukan tarjîh ${ }^{23}$ atas hasil ijtihad yang telah ada untuk kemudian ditetapkan dan digunakan pendapat yang paling kuat; (3) Melakukan kajian ulang atas pendapatpendapat fiqh yang telah ada, dengan cara menguji pendapatpendapat tersebut dengan kaidah-kaidah fiqh dan ushul fiqh, untuk melihat pendapat mana yang paling relevan dengan kondisi yang dihadapi oleh seorang mufti sebelum mengeluarkan fatwa; (4) Mengambil salah satu pendapat fiqh dalam mazhab tertentu untuk diikuti dan dijadikan dasar berfatwa. Keempat metode tersebut dilakukan dalam rangka penyusunan kitab Majallah. Artinya materi hukum yang terdapat dalam kitab Majallah bukanlah murni hasil ijtihad para ulama Turki, tetapi hanya diambil dari pendapat fiqh yang telah ada setelah dilakukan takhrij dan tarjih atas pendapat-pendapat fiqh yang ada dalam mazhab Hanafi.

Sumber penulisan kitab Majallah kebanyakan diambil dari kitab-kitab fiqh yang mu'tabar karya imam-imam besar mazhab Hanafiyah. Kitab-kitab fiqh yang menjadi sumber kitab Majallah dapat disebutkan sebagai berikut: (1) Kitab al-Amwâl dan kitab al-Haraj karya Abu Yusuf (w. 798 M); (2) Kitab al-Asl, al-Jamî̀ al-Kabîr, al-Jamî̀ alShaghîr, dan al-Ziyâdat karya Imam Muhammad Syaibani (w. 805 M); (3) Kitab Bidâyah al-Sanayi karya al-Kasani (w. $1191 \mathrm{M}$ ); (4) Kitab alHidâyah karya al-Marginani (w. 1197 M); serta beberapa kitab lainnya karya Imam Zafer ibn Huzail (w. 775 M), al-Asrâr karya al-Dabusi (w. 1047 M), al-Muhtashar karya Abu Ja'far al-Thahawi (w. 933 M), alNawâzil karya Abu Laits al-Samarqandhi (w. 983 M), Fath al-Qadîr karya Ibn Humam, Bahr al-Rấ'iq karya Ibn Nujaim, dan Radd al-Muhtâr karya Ibn Abidin (w. 1836 M).

22 Takhrij al-hukm adalah mengeluarkan hukum dari sumbernya (yakni alQur'an dan Sunnah) dengan menggunakan metode-metode ijtihad dan kaidahkaidah dalam ilmu figh dan ushul fiqh. Lihat Ibn Qayim al-Jauziyah, I'lam alMuwâqi'în, juz 4, Mesir: t.p., t.th, h.213. Takhrij dalam konteks penyusunan kitab Majallah tidak berarti melakukan ijtihad murni atas suatu permasalahan baru yang belum ada ketentuan hukumnya, tetapi sekedar mengeluarkan ulang hukum yang telah ada dalam fiqh Hanafiyah lengkap beserta dalil dan metodenya.

23 Tarjih menurut pendapat jumhur ulama adalah menguatkan salah satu dalil yang hanni dari yang lainnya untuk diamalkan berdasarkan dalil tersebut. Jumhur ulama mengkhususkan tarjih pada permasalahan yang zhanni. Karena hakekatnya tarjih dalam konteks fiqh tidak termasuk persoalan yang qath'i dengan yang qath'i, juga tidak termasuk antara yang qath'i dengan yang zhanni. Lihat Rahmat Syafei, Ilmu Ushul Figh, (Bandung: Pustaka Setia, 1999), h. 242-243. 
Mengenai metode aplikasi konsep fiqh dalam kitab Majallah, para hakim Usmaniyah mengikuti dan menggunakan kaidah-kaidah fiqh Ibn Nujaim yang terdapat dalam kitab Al-Asbah wa al-Nadhấir. Terutama untuk perkara-perkara baru yang belum dibahas sebelumnya dalam kitab-kitab fiqh, maka mutlak diperlukan kaidahkaidah fiqh untuk menyelesaikannya. Selain itu untuk memudahkan para hakim dan masyarakat luas dalam memahami isi kitab Majallah, pada bagian muqadimah kitab tersebut dilengkapi dengan penjelasan istilah-istilah yang lazim digunakan dalam kitab-kitab fiqh Hanafiyah. ${ }^{24}$

\section{Kritik Terhadap Kitab Majallah}

Layaknya sebuah hasil pemikiran manusia, kitab Majallah tidak luput dari kritikan para ahli hukum, baik ahli hukum Turki sendiri maupun ahli hukum dari luar Turki. Beberapa pakar hukum Turki kontemporer ${ }^{25}$ melakukan studi mendalam tentang kitab Majallah, dari kajian tersebut mereka menulis beberapa kritikan terhadap sistem, struktur, dan bahkan kandungan materi hukum dalam kitab Majallah. Di antara beberapa pokok kritikan tersebut adalah:

1. Dari sisi mantik hukum, beberapa pembagian bab maupun pasal dalam kitab Majallah tampak tidak sinkron dan tidak sistematis.

2. Dilihat dari cakupannya sebagai sumber hukum perdata modern, kitab Majallah tidak mencakup secara lengkap bidangbidang cakupan hukum perdata seperti hukum keluarga (hukum pernikahan dan hukum kewarisan). Ketidaklengkapan tersebut menyebabkan kekosongan hukum perdata di Turki, sehingga pemerintah Turki di kemudian hari menyusun secara tersendiri undang-undang hukum perdata lain seperti Undangundang Hukum Pernikahan (Hukuki Aile Kararnamesi) dan Undang-undang Hukum Piutang (Turk Borclar Kanunu).

3. Terjadi pengulangan yang dianggap tidak perlu pada beberapa pasal dalam kitab Majallah.

4. Kitab Majallah hanya bersumber dari satu mazhab pemikiran hukum Islam saja dalam menjawab permasalahan umat. Hal

24 Hayreddin Karaman, Islam Hukuk Tarihi, h. 314.

25 Di antara pakar hukum Turki modern yang melakukan kritik terhadap kitab Majallah adalah prof. Findikoglu, prof. Barkan, dan prof. Hifzi Veldet. Lihat Abu al-Ula Mardin, Medeni Hukuk, h. 186-226. 
demikian dianggap tidak mencukupi kebutuhan hukum masyarakat modern.

5. Ada kalanya susunan kalimat pada beberapa pasal dalam kitab Majallah sulit dipahami.

6. Metode dan sistematika yang digunakan tampak tumpang tindih dan tidak memenuhi standar kitab undang-undang modern.

Kritik para pakar hukum Turki modern tersebut dapat juga dipahami secara politis sebagai bentuk dukungan pemerintah dalam menerapkan sistem hukum Barat modern - yang dalam hal ini adalah sistem hukum Perancis - pasca tidak diberlakukannya kitab Majallah sebagai sumber huum perdata di Turki tahun 1926. ${ }^{26}$

Sementara itu kritikan yang lain terhadap kitab Majallah diungkapkan oleh pakar hukum Islam kontemporer Universitas Damaskus, Mustafa Ahmad Zerka. Beberapa poin kritikannya yaitu:

1. Apabila dilihat dari sistem penulisan materi hukumnya, banyak sekali pasal-pasal yang ditulis dengan penjelasan yang panjang. Hal ini membuat kitab Majallah tidak tampak seperti kitab Undang-undang, tetapi lebih menyerupai kitab-kitab fiqh biasa yang tidak memenuhi standar sebagai sebuah Kitab Undangundang Hukum Perdata modern. ${ }^{27}$

2. Kitab Majallah selain memuat materi hukum perdata juga memuat apa yang dalam istilah ilmu hukum modern disebut sebagai "Hukum Peradilan" atau "Ushûl al-Ahkâm". Jika dilihat dari konteks sistem hukum modern, sebagai sebuah Kitab Undang-undang Hukum Perdata tidak seharusnya bercampur aduk dengan Undang-undang Hukum Peradilan. Dengan kata lain, antara keduanya harus dipisah secara tersendiri, karena tidak semestinya dalam satu kitab perundangan memuat dua peraturan perundangan yang berbeda. ${ }^{28}$

3. Kitab Majallah hanya bersumber dari satu pemikiran mazhab saja, yakni mazhab Hanafi. Menurut Ahmad Zerka, berpegang hanya pada satu mazhab pemikiran fiqh saja pada zaman sekarang tidak akan cukup untuk menyelesaikan permasalahan umat. Idealnya diperlukan pandangan semua mazhab fiqh

${ }^{26}$ Lihat Turgut Akinturk dan Derya Ates Karaman, Medeni Hukuk, (Istanbul: Beta Basim A.S., 2012), h. 47.

27 Mustafa Ahmad Zerka, Al-Madkhal al-Figh al-'Amm, h. 242.

28 Ibid, h. 242-243. 
untuk menjadi sumber rujukan pemecahan masalah hukum Islam modern. Menurutnya, seandainya kitab Majallah di awal penyusunannya mengakomodasi semua pemikiran mazhab fiqh, tentunya kitab tersebut akan lebih komprehensif dan lebih maslahah serta akan lebih relevan dengan permasalahan umat pada masa sekarang. ${ }^{29}$

Apabila dilihat dari bentuk susunannya, kitab Majallah lebih tampak sebagai ringkasan kitab-kitab fiqh daripada sebagai sebuah kitan Undang-undang Hukum Perdata. Hanya saja karena kitab tersebut secara resmi menjadi bagian dari konstitusi negara, menjadi salah satu sumber hukum perdata Turki Usmaniyah, maka setiap keputusan hukum yang berdasarkan kitab tersebbut menjadi "qadha" yang harus ditaati, mengikat, dan memiliki kekuatan hukum tetap. Hal ini berbeda dengan kitab-kitab fiqh lainnya yang tidak secara resmi menjadi bagian dari sumber hukum negara, sehingga pandangan hukum yang bersumber dari kitab-kitab fiqh selain kitab Majallah sebatas menjadi "fatwa" yang tidak mengikat, serta tidak memiliki kekuatan hukum tetap.

Terlepas dari kelemahan-kelemahannya sebagaimana disebutkan sebelumnya, apabila dilihat secara kontekstual penyusunan kitab Majallah, sebenarnya kitab tersebut merupakan karya cemerlang pada masanya karena diantara kelebihannya kitab Majallah telah terbukti memenuhi fungsinya sebagai pemersatu pandangan hukum para hakim sekaligus sebagai sumber hukum yang memudahkan pengambilan hukum sebagaimana yang dibutuhkan umat Islam pada masa itu. Yang lebih penting lagi, keberadaan kitab Majallah sesungguhnya telah menjadi sumber inspirasi dari munculnya gerakan kodifikasi hukum Islam di dunia Islam pada awal abad ke-20 hingga sekarang yang menunjukan sebagai salah satu keistimewaan yang melekat pada kitab Majallah.

Kelemahan-kelemahan kitab Majallah tersebut tampaknya menjadi sebab kitab tersebut tidak diberlakukan lagi di seluruh wilayah Turki, meskipun tidak sepenuhnya ditinggalkan. Karena sebagian wilayah yang dulu menjadi bagian dari kekhalifahan Turki Usmaniyah masih menerapkan kitab Majallah hingga munculnya gerakan kodifikasi hukum Islam di negara-negara Islam. 


\section{Kedudukan Kitab Majallah dalam Tata Hukum Turki Modern}

Kitab Majallah al-Ahkâm al-Adliyyah telah resmi menjadi bagian dari sumber hukum pemerintah Turki selama 57 tahun pasca kodifikasi kitab tersebut pada masa kekhilafahan Usmaniyah sekitar tahun 1869 Mhingga bergulirnya revolusi di Turki yang merubah Turki menjadi sebuah negara republic yang sekuler pada tahun 1922 M. dan kitab Majallah masih tetap diberlakukan hingga diundangkannya Undang-undang Hukum Perdata Turki yang baru yang disebut "Turk Medeni Kanunu" pada tahun 1926 M.

Turk Medeni Kanunu adalah kitab Undang-undang Hukum Perdata Turki modern yang menggunakan sistem tata hukum Perancis yang memuat beberapa bidang cakupan hukum perdata seperti hukum personal (Kisiler Hukuku), hukum keluarga (Aile Hukuku), hukum kewarisan (Miras Hukuku), hukum properti (Esyalar Hukuku), serta hukum piutang (Borclar Hukuku). Berbeda dengan kitab Majallah, dalam Turk Medeni Kanunu tidak terdapat Hukum Peradilan (Yargilama hukuku) karena dalam sistem perundang-undangan modern, hukum peradilan biasanya dipisahkan dari perundang-undangan lainnya.

Turk Medeni Kanunu pada awal diresmikannya menjadi kitab Undang-undang Hukum Perdata Turki pada tanggal 4 oktober $1926 \mathrm{M}$ hanya terdiri dari 544 pasal dan 818 sub pasal. Setelah mengalami amandemen pada tanggal 1 oktober 2002 berubah menjadi 1030 pasal dan 4721 sub pasal. ${ }^{30}$ Dalam Turk Medeni Kanunu, undang-undang tentang hukum muamalah atau yang berkaitan dengan transaksi ekonomi tercakup di dalam bagian hukum properti (Esya Hukuku), hukum piutang (Borclar Hukuku), dan juga hukum perdagangan (Ticaret Sirketleri Hukuku). ${ }^{31}$ Karena cakupan Turk Medeni Kanunu yang demikian luasnya dalam bidang-bidang hukum perdata Turki, maka kitab Majallah secara resmi tidak lagi diberlakukan sejak diundangkannya Turk Medeni Kanunu tersebut. Lantas dimana fungsi dan kedudukan kitab Majallah dalam tata hukum negara Turki modern, utamanya dalam kehidupan masyarakat muslim di Turki saat ini?

30 Turgut Akinturk dan Derya Ates Karaman, Medeni Hukuk, h. 47-48.

${ }^{31}$ Necip Bilge, Hukuk Baslangici, (Ankara: Turhan Kitabevi, 2012), h. 116-119. 
Berdasarkan hasil penelitian yang telah lakukan secara langsung di kota Istanbul Turki, ${ }^{32}$ setidaknya dapat menyimpulkan bahwa kitab Majallah masih menempati kedudukan yang fundamental dalam sisyem hukum di Turki, yakni:

Pertama, kitab Majallah menjadi spirit atau semangat penegakan hukum perdata Turki modern. Karena itu dalam pandangan beberapa pakar hukum Islam di Turki, apabila terdapat pasal-pasal dalam Turk Medeni Kanunu yang bertentangan dengan kitab Majallah, maka pasal tersebut tidak boleh diberlakukan. Itu artinya negara Turki masih memberlakukan kitab Majallah secara substansif. Meskipun kitab Majallah tidak lagi menjadi sumber hukum perdata Turki, tetapi substansinya masih tetap berlaku dan ditaati oleh rakyat Muslim di Turki hingga sekarang.

Kedua, kitab Majallah hingga saat ini masih menjadi sumber hukum muamalah masyarakat muslim di Turki secara privat. Melalui beberapa kali wawancara dengan para pedagang di pasar-pasar tradisional dan bahkan di beberapa mall besar di kota Istanbul, kitab Majallah bagi masyarakat muslim di Turki mungkin tidak lagi menjadi sumber hukum resmi untuk memutuskan persoalan muamalah, tetapi yang lebih penting adalah fungsinya sebagai pedoman dalam bermuamalah dengan maksud memperoleh penghasilan yang halal menurut hukum Islam. Artinya, masyarakat Turki masih menerapkan kitab Majallah secara informal sebagaimana mereka menerapkan fiqh mazhab Hanafi.

Apabila realitas tersebut dilihat dari sisi sistem tata hukum modern, maka dapat dikatakan bahwa kitab Majallah sebenarnya masih menjalankan fungsinya sebagai sumber hukum perdata Turki hingga sekarang, hanya saja dalam kedudukannya sebagai sumber

32 Hasil wawancara secara langsung antara tanggal 27 Januari hingga 20 Pebruari 2016 di kota Istanbul Turki. Responden yang diwawancarai dikelompokkan menjadi dua; (1) kelompok ahli hukum Turki. Di antaranya adalah beberapa pakar hukum Islam di Turki seperti prof. Bilal Aybakan dari Marmara University dan prof. Hamdi Furat dari Istanbul University. (2) kelompok masyarakat awam, diantaranya beberapa pedagang di pasar tradisional dan juga pedagang di mall-mall modern. Dalam hal ini kelompok ahli hukum berpendapat bahwa kitab Majallah tidak menjadi sumber hukum formal di Turki saat ini, tetapi menjadi ruh dan diterapkan secara substansial. Sementara kelompok awam berpendapat bahwa kitab Majallah bagi mereka bukan lagi berfungsi untuk memutuskan perkara muamalah, sama seali bukan, karena itu tugas para hakim di pengadilan. Kitab Majallah bagi mereka adalah sebagai pedoman yang mereka ikuti dalam bermuamalah agar didapatkan hasil yang halal. 
hukum informal. Namun apabila dilihat dari sisi kekuatan pengaruhnya dalam kehidupan warga muslim Turki, setidaknya hingga saat ini kitab Majallah masih dianggap sebagai warisan yang teramat penting dari ulama-ulama mazhab yang mereka cintai, yakni mazhab Hanafi. Sehingga meskipun kitab Majallah menempati posisi sebagai sumber hukum perdata informal, pengaruhnya masih tetap terjaga dan ditaati oleh masyarakat muslim di Turki modern sebagaimana ketika kitab tersebut masih berlaku sebagai sumber hukum formal.

\section{Simpulan}

Kodifikasi dan perundangan hukum Islam pertama didunia Islam dimulai pada masa penyusunan kitab Majallah al-Ahkâm alAdliyyah oleh pemerintahan Usmaniyah di Turki. Hal terpenting yang melatarbelakangi kodifikasi tersebut adalah adanya kesulitan yang dialami para hakim dalam menemukan rujukan hukum yang dapat mempersatukan pendapat mereka tentang masalah yang sama. Selain itu, hukum yang ada dinilai tidak selalu dapat menyelesaikan persoalan yang dihadapi, sehingga dibutuhkan undang-undang baru yang mampu menjawab kebutuhan tersebut. Maka disusunlah kitab Majallah dan secara resmi menjadi sumber Hukum Perdata Turki sejak 1869 M hingga 1926 M. Sistematika penyusunan kitabMajallah terdiri dari pengertian istilah-istilah dalam hukum Islam, kaidah-kaidah penetapan hukum Islam, materi hukum, serta hukum peradilan atau ushul al-hukm. Metode yang digunakan dalam penyusunan adalah metode takhrij dan tarjih terhadap kitab-kitab mu'tabarah mazhab Hanafi.

Sebagai hasil karya manusia, kitab Majallah tidak lepas dari kritik para pakar hukum modern, baik di dalam maupun diluar Turki. Diantara kelemahan kitab Majallah adalah sistem kodifkasinya yang tidak memenuhi standar sebagai Hukum Perdata dalam kacamata teori perundang-undangan hukum modern. Kelemahan lainnya adalah sumber kitab Majallah yang hanya bersandar pada satu mazhab, yakni mazhab Hanafi. Namun terlepas dari kelemahan-kelemahannya sebagai sumber hukum resmi pemerintah Usmaniyah, setidaknya kitab Majallah telah mampu memenuhi fungsinya sebagai pemersatu pandangan hukum para hakim sekaligus sebagai sumber hukum yang memudahkan pengambilan hukum sebagaimana yang dibutuhkan umat Islam pada masa itu. Serta menjadi sumber inspirasi dari 
munculnya gerakan kodifikasi hukum Islam di dunia Islam pada awal abad ke-20 hingga sekarang.

Meskipun kitab Majallah secara resmi sudah tidak lagi menjadi sumber hukum perdata di Turki, tetapi setidaknya kitab tersebut masih memiliki dua kedudukan penting dalam kehidupan hukum di Turki modern: (1) Sebagai spirit hukum perdata yang mana substansisubstansinya masih dipatuhi dan diterapkan; (2) Sebagai sumber hukum informal masyarakat muslim Turki dimana kitab Majallah berfungsi sebagai pedoman bermuamalah sehari-hari. Hal demikian karena mecintaan masyarakat Turki terhadap agama dan ajaran mazhab Hanafiyah yang mereka anut.

\section{DAFTAR PUSTAKA}

Akinturk, Turgut, Medeni Hukuk, Istanbul: Beta Basim A.S., 2012.

Anik, Mehmet, Two Axes Revolving Around the Discussions of Secularizm in Turkey, Istanbul: Ilem, 2012.

Atar, Fahretin, Fikih Usulu, cet. Ke-10, Istanbul: 2013.

------, Islam Yargilama Hukukun Esaslari, Istanbul: MU Ilahiyat

Yayinlari, 2012.

----------, Tanzîmat Fermani, Diktat Mata Kuliah Islam Yargilama Hukuku, 2012.

Aydin, M. Akif, Turk Hukuk Tarihi, Istanbul: Beta Yayinlari, 2013.

Berkes, Niyazi, The Development of Secularizn in Turkey, Mc Gill: Mc Gill University Press, 1964.

Bilge, Necip, Hukuk Baslangici, Ankara: Turhan Kitabevi, 2012.

Hitti, Philip K., History of the Arab, cet. Ke-10, New York: Mac Millan, 1976.

Ibn Qayim al-Jauziyah, I'lam al-Muwâqi'în, juz 4, Mesir: t.p., t.th.

Karaman, Hayreddin, Islam Hukuk Tarihi, Istanbul: Iz Yayincilik, 2012.

Mardin, Abu al-Ula, Medeni Hukuk Cephesinden Ahmed Cevdet Pasha, Istanbul: Istanbul Yayinlari, 1946.

Ozturk, Ozman, Osmanli Hukuk Tarihinde Mecelle, Istanbul: Iz Yayincilik, 1973.

Syafei, Rahmat, Ilmu Ushul Figh, Bandung: Pustaka Setia, 1999.

Tabakoglu, Ahmed, Islam Iktisadina Giris, Istanbul: Dergah Yayinlari, 2008.

Tohari, Chamim, Figh Keindonesiaan: Transformasi Hukum Islam Dalam Sistem Tata Hukum Di Indonesia, Jurnal Analisis, Vol. 15, No. 2, Desember 2015. 
Zerka, Mustafa Ahmad, Al-Madkhal al-Figh al-'Amm, Jilid I, Jeddah: Dâr al-Bashîr, 2004.

Zurcher, Erik J., Turkey A Modern History, London-New York: I.B. Touris \& Co. Ltd, 1994. 